\title{
Maturity and Safety of Compost Processed in HV and TW Composting Systems
}

\author{
Kutsanedzie F. ${ }^{1,}$, Ofori , $^{2}$, Diaba K. S. ${ }^{3}$ \\ ${ }^{1}$ Research and Innovation Department, Accra Polytechnic, Accra, Ghana \\ ${ }^{2}$ Agricultural Engineering Department, Kwame Nkrumah University of Science and Technology, Kumasi, Ghana \\ ${ }^{3}$ AgriculturalEngineering Department, Anglican University College of Technology, Sunyani, Ghana \\ Email address: \\ fkutsanedzie@apoly.edu.gh (Kutsanedzie F.)
}

\section{To cite this article:}

Kutsanedzie F., Ofori V., Diaba K. S.. Maturity and Safety of Compost Processed in HV and TW Composting Systems. International Journal of Science, Technology and Society. Vol. 3, No. 4, 2015, pp. 202-209. doi: 10.11648/j.ijsts.20150304.24

\begin{abstract}
Two composting systems: passive aerated system, horizontal-vertical system; active aerated system, turned windrow system was designed, constructed and studied for thirteen weeks to compare the maturity and safety of compost processed in them. Waste materials with the following percentage composition: river reed (75\%), clay (10\%), banana stalk / stem (5\%), cow manure / dung (4\%), rice chaff (4\%), cocoa seed husk $(1 \%)$, and poultry manure $(1 \%)$ was processed in the two different systems. Compost materials were weekly sampled from top, bottom and mid portions of the compost masses in each of the systems and bulked to constitute a representative sample for the respective systems. From the weekly representative samples for the two systems, $5 \mathrm{~g}$ subsamples were used for the determination of the germination index and microbial load for the compost masses. However temperature readings of the compost masses in both systems were recorded insitu daily at three different points using a long stem thermometer and the their respective averages used as the weekly readings for the systems. Temperature and the germination indices of composts processed in the two systems were used as parameters to assess the maturity; and the microbial load and its survival to assess the safety of the compost churned out. There were significant differences in the temperatures recorded in the two different systems during the composting period ( $\mathrm{p}$-value $=4.75 \times 10-7$, at $\alpha=0.05$ ). The total viable counts recorded in HV and TW ranged between $6.90-7.75 \log$ CFU/g of compost and 7.11-7.79logCFU/g of compost respectively which were significantly different ( $\mathrm{p}$-value $=0.027$, at $\alpha=0.05$ ). The total fungi counts recorded in $\mathrm{HV}$ and T-W ranged between $1.11-2.32 \log \mathrm{CFU} / \mathrm{g}$ of compost and $1.68-2.40 \log \mathrm{CFU} / \mathrm{g}$ of compost respectively. Compost masses in all the systems had germination indices more than $150 \%$.T-W had a higher rate of decomposition and maturity comparatively, hence a better composting system based on compost maturity. Penicillium spp. survived the process and it is known to produces mycotoxins which cause illnesses in humans. It is recommended that compost end-users, farmers, and producers use protectives and observe good hygiene in order to safeguard their health.
\end{abstract}

Keywords: Passive Aerated Systems, Active Aerated Systems, Germination Index, Maturity

\section{Introduction}

Composting has been an organic waste management method used for the production of organic fertilizer worldwide. Organic grown foodstuff are highly priced and considered as healthy compared to food grown with chemical fertilizers. Many types of soil-borne pathogens commonly found in soilless potting media are known to be disease causing and also negatively affect yields (Inbar et al., 1993). However compost suppresses these pathogens but the degree of suppression depends on the maturity and type of compost (Ben-Yephet \& Nelson, 1999; Hoitink et al., 1997).
Scientists worldwide have been researching on the parameters and methods that yield safe and matured compost within short duration because of its demand for the growing of crops and other horticultural plants.

There are several types of systems used in composting of organic matter but all these different systems are classified broadly into two: passive aeration and active aeration systems. Passive aeration systems are those which are expected to aerate themselves once the process has been set whereas active aerated systems involves using human or machine 
power to provide aeration for the composting process. According to Sundberg (2005) some common systems includes naturally aerated windrow systems-long rows with triangular cross section; forced aeration static pile systems; tunnel systems-closed rotating cylinders (Sundberg 2005). Sherman (2005) describes passive systems of composting as requiring very little attention while static heaps are maintained through forced aeration or frequent mechanical turning. According to Hao et al. (2001), passive aeration is not as effective as turning in the decomposition of organic matter as observed from the result of the analysis of $\mathrm{CO}_{2}$ and other gases in composting feedlot manure. Improvement in the aeration in a composting pile has been found to reduce the production of $\mathrm{CH}_{4}$ production which is a more harmful greenhouse gas compared to $\mathrm{CO}_{2}$ when a forced aeration system is used (Lopez-Real \& Baptista, 1996).

Various parameters that have been used to assess the safety and maturity of composts include the $\mathrm{C}: \mathrm{N}$ ratio of the finished product, water soluble carbon, cation exchange capacity, humus content, and the carbon dioxide evolution from the finished compost (Garcia et al., 1992; Huang et al., 2001). Germination index, which is a measure of phytotoxicity, has been considered as a reliable indirect quantification of compost maturity (Cunha Queda et al., 2002). Ikeda et al. (2006) compared the germination index method with other methods, using both immature composts and mature composts sold as products. It was observed that the more the decomposition from livestock faeces came to maturity, the higher the germination index became. It was concluded that the germination index method is a highly accurate maturity parameter, under the conditions of setting more than $150 \%$ as a maturity standard, using 5 days for seed cultivation. However, degradation of organic materials during composting is done by bacteria, fungi, and actinomycetes, depending on the stage of decomposition, the characteristics of materials, and temperature (Epstein, 1996; USDA, 2000). Bacteria are organisms responsible for compost decomposition and thermophilic bacteria. Pathogens in compost are killed or reduced at temperature above $55^{\circ} \mathrm{C}$ (Strom, 1985).

According to Canada Composting Council (2008) at least two of following must be met for compost to be declared mature: $\mathrm{C} / \mathrm{N}$ ratio is less than or equal to 25 ; oxygen uptake rate is less than or equal to $150 \mathrm{mg} \mathrm{O}_{2} / \mathrm{kg}$ volatile solids per hour; germination of cress (Lepidium sativum) seeds and of radish (Raphanus sativus) seeds in compost must be greater than 90 percent of the germination rate of the control sample, and the growth rate of plants grown in a mixture of compost and soil must not differ more than 50 percent in comparison with the control sample; Compost must be cured for at least 21 days; Compost will not reheat upon standing to $20^{\circ} \mathrm{C}$ above ambient temperature.

Sequel to the criteria of Canada Composting Council (2008), this study uses the temperature and the germination indices of composts processed in the two systems to assess the maturity; and the microbial load and microbial survival to assess the safety of composts processed in two composting systems: passive aerated system, horizontal-vertical (HV) system; active aerated system, turned windrow (TW) system.

\subsection{Problem Statement}

Effective and efficient composting systems must churn out composts that are safe and matured earlier if compost is to be prepared on sustainable basis for application on large scale organic farms. Thus the most efficient and effective system to achieve this needs to be selected. This has necessitated the need to compare compost maturity and safety in horizontal-vertical system and turned windrow system for large scale compost production.

\subsection{Objective}

The main objective of this paper is to design as experiment to compare the compost maturity through the use of germination index and temperature; and safety in terms of microbial loads and microbial survival in the two stated systems.

\subsection{Area of Study}

Volta River Estate Limited Farms (VREL) is located at Akrade in the Eastern Region of Ghana and owns five farms. They are engaged in banana and pineapple production on large scales. The organic fertilizer used on these farms is prepared via composting using waste materials such as river reed, clay, banana stalk/stem, cow manure/dung, rice chaff, cocoa seed, husk, poultry manure from the farm and environs.

\subsection{Description of Systems}

\subsubsection{Horizontal-Vertical Aeration Technology}

The horizontal-vertical aeration technology, known as the $\mathrm{T}-\mathrm{W}$ aeration is a passive system. It uses of 6 in. diameter uPVC pipes with perforated holes to effect the passive aeration. The pipes are inverted T-shaped, with perforations on the horizontal section allowing ambient air to move into the pile and that of the vertical, allows warm and waste gases to exit compost mass. The dimension of the pile is $6.8 \mathrm{~m}$ $(\mathrm{L}) \times 2.6(\mathrm{~B}) \mathrm{m} \times 1.7 \mathrm{~m}(\mathrm{H})$ and covered with the Toptex (fleece) sheet after mounting the piles. The vertical pipe was perforated to about $1.2 \mathrm{~m}$ high from the bottom.

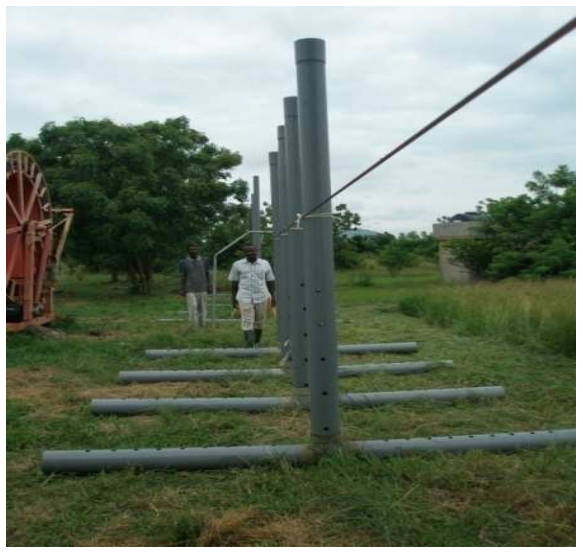

Figure 1. Perforated uPVC pipes. 


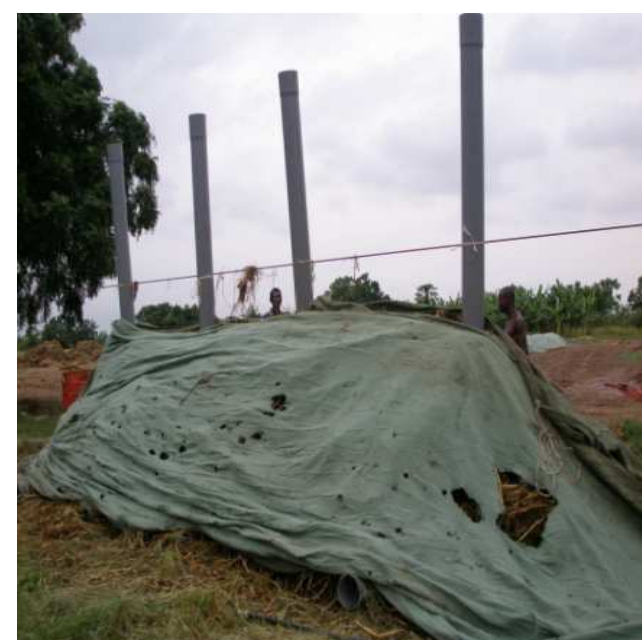

Figure 2. Prepared pile in HV.

\subsubsection{Turned Windrows (TW)}

With the turned windrow system, the dimension of the TW pile is $35 \mathrm{~m}(\mathrm{~L}) \times 2 \mathrm{~m}(\mathrm{~B}) \times 0.9 \mathrm{~m}(\mathrm{H})$. Turning was conducted on the condition that temperature or $\mathrm{CO}_{2}$ levels exceed $650 \mathrm{C}$ or $20 \%$ respectively and done with the Sandberger ST 300 pulled by a $90 \mathrm{HP}$ tractor. However, turning was done initially four times and a front-loader $(165 \mathrm{HP})$ was used to reshape the pile after which a Toptex (fleece) sheet was used to cover the windrow. On the average, windrow is turned about 6-8 times during the first 2 weeks after which the row was left alone as much as possible.

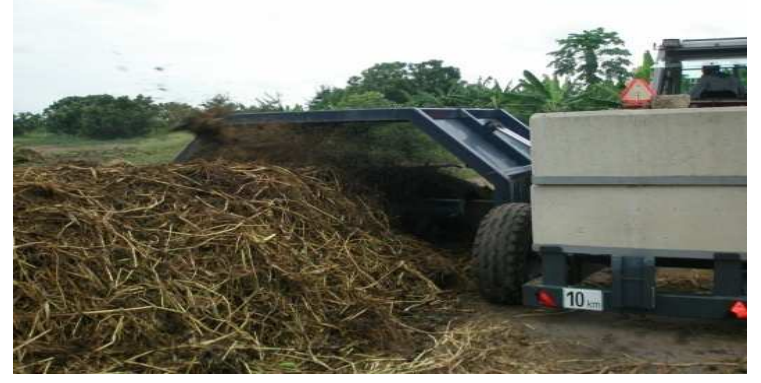

Figure 3. Sandberger ST 300 turning Feed stock pile.

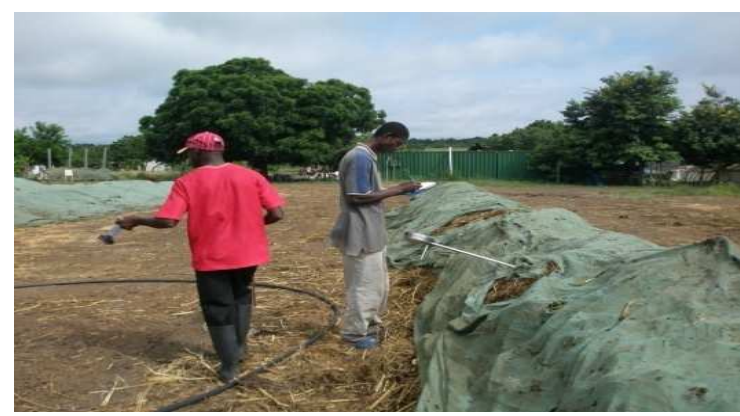

Figure 4. Covered windrow pile.

\section{Materials and Methods}

Compost prepared under the two systems consisted of the following in the proportion below: River Reed (RR), $75 \%$;
Clay(C), 10\%; Banana Stalk/Stem (BS),5\%; Cow Manure/Dung (CM), 4\%; Rice Chaff (RC), 4\%; Cocoa Seed Husk (CSH), 1\%; Poultry Manure (PM), 1\%. A starter (Soil Tech

Solution) containing genetically modified organisms such as Bacillus spp. and Corynebacterium spp. was mixed in the proportion $500 \mathrm{~g}$ in $40 \mathrm{~L}$ water and added to the feedstocks to facilitate the decomposition process.

\subsection{Sampling of Compost Mass for Physicochemical and Microbiological Analysis in the Laboratory}

Compost masses were sampled at the top, middle and bottom in the two different systems mounted for the research with a forcep every week for laboratory study. The samples taken were bulked to obtain a representative sample. Samples were packed with ice cubes in an ice chest and transported each and every week to the laboratory where they were kept in afreezer at a temperature of $20{ }^{\circ} \mathrm{C}$ for a day before microbial analysis was performed.

This experiment was carried out for thirteen (13) weeks, starting from week 0 to week 12 with averaged weekly temperatures; total viable count, coliform count and fungi count; and the germination indices of compost mass in each system determined.

\subsection{Temperature Determination}

Temperature readings were taken daily from three different sides: top, middle and bottom for 13 weeks in the two composting systems using the long stem thermometer (Salmoiraghi Co. thermometer model 17506) at the site. The daily ambient temperatures were also taken.

\subsection{Germination Index Determination}

The germination index was determined for compost prepared in both sysyems using the method described by Zucconi (1981), and was computed using the formula expressed as follows:

Relative seed germination(\%)

$=\frac{\text { No. of seeds germinated in litter extract }}{\text { No. of seeds germinated in control }} \times 100$

Relative root growth(\%)

$$
\begin{aligned}
= & \frac{\text { Mean root length in litter extract }}{\text { Mean root length in control }} \times 100 \\
\mathrm{GI} & =\frac{(\% \text { Seed germination }) \times(\% \text { Root elongation })}{100}
\end{aligned}
$$

Where GI $=$ Germination Index

\subsection{Serial Dilution for Total Viable, Coliform Count and Fungi Count}

$1 \mathrm{~g}$ of representative samples taken from each of the systems mounted for study was weighed into $9 \mathrm{ml}$ of $0.1 \%$ peptone water contained in 4 different McCartney bottles and 
incubated at $37^{\circ} \mathrm{C}$ for 15 minutes. They were mixed well and $1 \mathrm{ml}$ of the supernatant was drawn from each of the bottles and diluted using 10-fold dilution into 4 other McCartney bottles each containing $9 \mathrm{ml}$ of sterile $0.1 \%$ blank peptone water. Different pipettes were used for each of the dilution. $1 \mathrm{ml}$ of the diluents taken from dilution factors: 1:103,1:104 and 1:105 were transferred into 2 sets of 3 different McCartney bottles one set containing $9 \mathrm{ml}$ of molten Plate Count Agar (PCA) and the other set $9 \mathrm{ml}$ of Violet Red Bile Agar. Both sets were kept in a water bath at $45{ }^{\circ} \mathrm{C}$ to prevent solidification (Collins \& Lyne, 1983).

Identification of bacteria was based on the examination of slides of Gram stained microorganisms prepared from pure cultures grown on blood agar, MacConkey agar, Brilliant Green agar and Eosin Methylene Blue agar .The Brilliant Green agar and Eosin Methlyene Blue agar were plated to aid the identification of Salmonella spp. and Escherichia spp. respectively. Slides were observed using the light microscope at $\mathrm{x} 100$ with oil immersion. The colonial and cell morphology of microorganisms and reactions to the Gram stain were used in bacteria identification Fungi were identified using their colonial morphology and colour reaction on sabouraud agar in labeled Petri-dishes and incubated at $30^{\circ} \mathrm{C}$ for $2-7$ days.

Slides kept in $90 \%$ alcohol were dried. The wire loop was flamed and two loopfuls of distilled water was placed at the centre of a cleaned slide. The wire loop was lightly used to touch the identified colony on a plated pure culture, and then gently mixed with the distilled water to dilute their concentration and was spread over the centre of the slide to cover approximately $3 \mathrm{~cm} \times 1 \mathrm{~cm}$

\section{Results and Discussion}

\subsection{Effects of Temperature on the Factors Determined in the Turned-Windrow System}

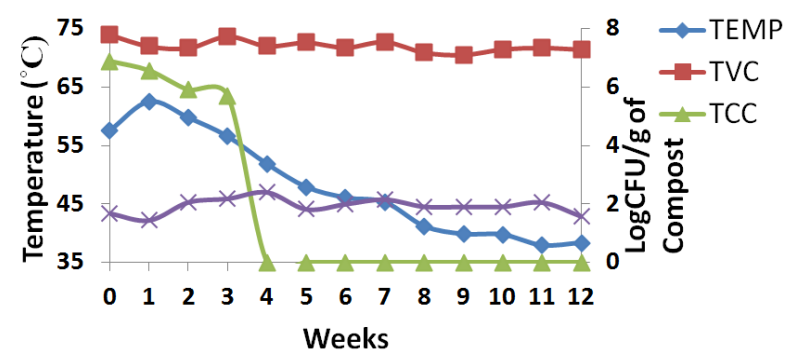

Figure 5. Variations in Temperature, Total Viable Count, Total Coliform Count and Total Fungi Count in the T-W system.

\subsubsection{Total Viable Count}

The total viable count decreased from $7.79 \log \mathrm{CFU} / \mathrm{g}$ of compost to $7.40 \log \mathrm{CFU} / \mathrm{g}$ of compost with a rise in temperature from $57.60^{\circ} \mathrm{C}$ to $62.56^{\circ} \mathrm{C}$ during week 0 to week 1 as shown in figure 5 . Temperature fell gradually from week 2 to week 7 but was within the thermophilic range. This temperature range caused almost uniform rises and falls in the total viable count during week 2 to week 7 . As the temperature fell to $41.17^{\circ} \mathrm{C}$ (mesophilic condition) during week 8 , total viable count decreased to $7.19 \log \mathrm{CFU} / \mathrm{g}$ of compost. There was a rise in the total viable count from week 10 to 11 and a slight fall in week 12 when temperature fell within the mesophilic range. It was noted also that the percentage frequencies of Corynebacterium spp. increased from week 9 to week 12.

The fall in the total viable count during week 12 might be due to nutrient depletion. The gradual fall in temperature toward the end of the process indicated the stability and maturity of the compost. The bacteria identified during the process were Bacillus spp., Staphylococcus spp., Streptococcus spp., Clostridium spp., Campylobacter spp., Listeria spp., Corynebacterium spp., Yersinia spp. and Enterobacter spp. Those that survived the process were the Bacillus spp. (28.57\%) and Corynebacterium spp. (71.43\%).

\subsubsection{Total Coliform Count}

The total coliform count decreased from $6.88 \log \mathrm{CFU} / \mathrm{g}$ of compost to $6.56 \log \mathrm{CFU} / \mathrm{g}$ of compost with rise in temperature from $57.60^{\circ} \mathrm{C}$ to $62.56^{\circ} \mathrm{C}$ during week 0 to week 1 as seen in figure 5 . The total coliform count decreased with decreased temperature during the subsequent weeks until week 4 when the total coliform count yielded $0 \log \mathrm{CFU} / \mathrm{g}$ of compost at a temperature of $51.83^{\circ} \mathrm{C}$.The total coliform count of $0 \log \mathrm{CFU} / \mathrm{g}$ of compost obtained in week 4 indicated the reduction of faecal contamination. Enterobacter spp. was the only coliform identified during the process.

\subsubsection{Total Fungi Count}

Total fungi count decreased from $1.68 \log$ CFU/g of compost to $1.45 \log \mathrm{CFU} / \mathrm{g}$ of compost with increased in temperature from $57.60^{\circ} \mathrm{C}$ to $62.56^{\circ} \mathrm{C}$ during week 0 to week 1 as shown in figure 5 . The total fungi count increased as temperature fell from week 1 to week 4 and subsequently declined in week 5 . The total fungi count further rose to values ranging between $1.90 \log \mathrm{CFU} / \mathrm{g}$ of compost to $2.15 \mathrm{log} \mathrm{CFU} / \mathrm{g}$ of compost during week 6 to week 11. There was a fall in the total fungi count in week 12. This distribution of fungi during 6 to 11 confirms the fact that they tolerate low temperature and largely present at the latter stages of composting to decompose cellulose, chitin and lignin. The fungi identified during the process were Penicillium spp., Aspergillus spp., Mucor spp. and Rhizopus spp. The only fungus that survived the process was Penicillium spp.

\subsubsection{Germination Index}

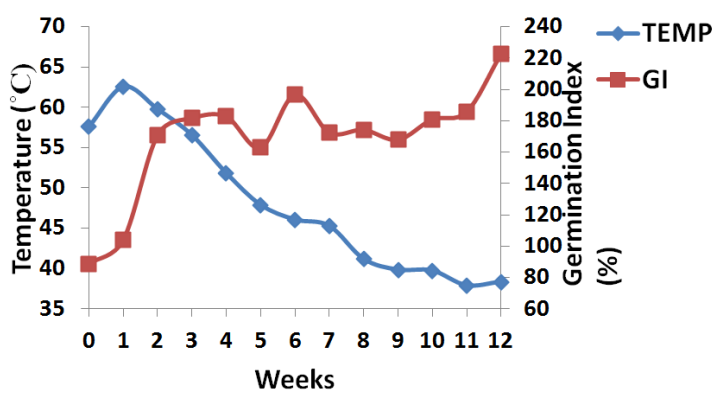

Figure 6. Variations in Temperature and Germination Index in the $T-W$ systems. 
As temperature increased from $57.60^{\circ} \mathrm{C}$ to $62.56^{\circ} \mathrm{C}$ during week 0 to week 1 , the germination index increased from $88.58 \%$ to $103.89 \%$ as illustrated in figure 6 . When temperature decreased the subsequent weeks, germination index increased until a decrease was recorded during week 5 . There was a fall in the percentage frequency of Bacillus spp., though a rise in the total viable count was recorded during week 5. The rise in the germination index during week 6 could also be attributed to the rise in the level of Bacillus spp., though there was a decrease in the total viable count as seen in Figure 7. The final germination index recorded in the system was $222.64 \%$.

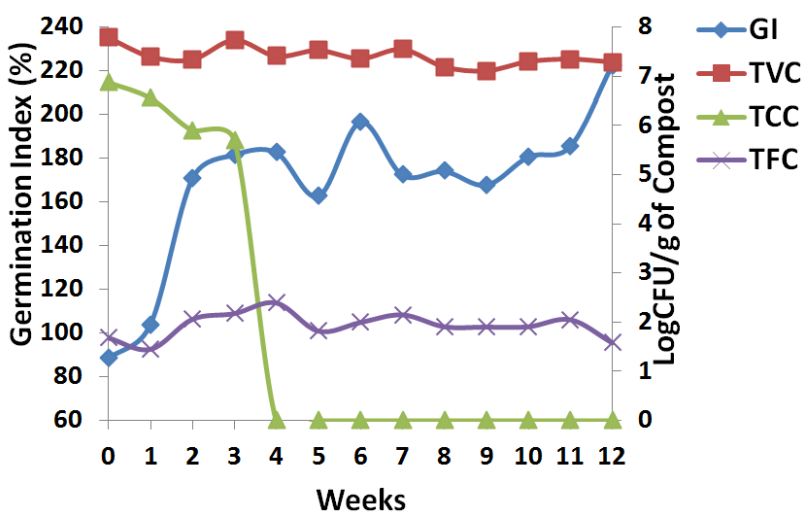

Figure 7. Variations in Germination Index, Total Viable Count, Total Coliform Count and Total Fungi Count in the T-W system.

\subsection{Effects of Temperature on Factors Determined in the Horizontal-Vertical Technology}

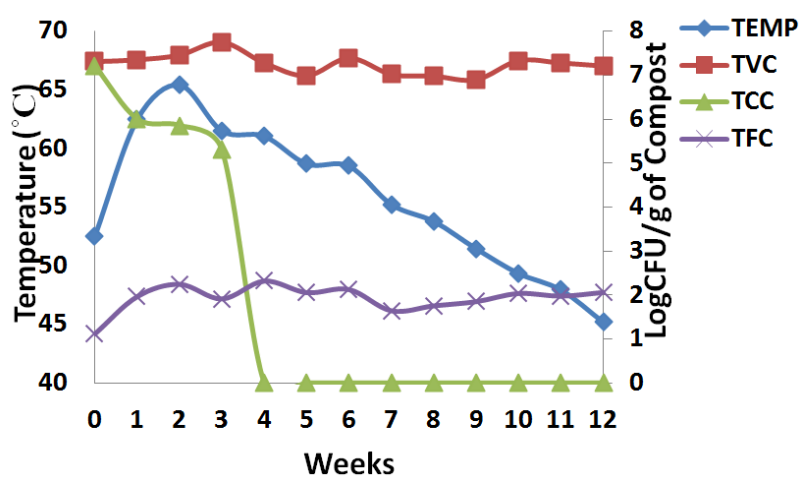

Figure 8. Temperature variations on Total Viable Count, Total Coliform Count and Total Fungi Count in HV system.

\subsubsection{Total Viable Count}

Figure 8 shows that as temperature increased from $52.49^{\circ} \mathrm{C}$ in week 0 to $65.44^{\circ} \mathrm{C}$ in week 2 , there was a slight rise in the total viable count from $7.31 \log \mathrm{CFU} / \mathrm{g}$ of compost to $7.46 \log \mathrm{CFU} / \mathrm{g}$ of compost. Rise in temperature during week 3 caused a fall in the total viable count. The total viable count ranged between $7.28 \log \mathrm{CFU} / \mathrm{g}$ of compost and $6.90 \mathrm{log} \mathrm{CFU} / \mathrm{g}$ of compost from week 4 to week 10 with a fall in temperature from $61.07^{\circ} \mathrm{C}$ to $49.35^{\circ} \mathrm{C}$. Temperature fell gradually from the week 3 to week 12. However, the total viable count began to fall from week 10 to week 12 .The rise and fall in total viable count between week 2 and week 6 shows that some microorganisms were being inactivated and favoured at different temperatures during the composting process leading to succession of different organisms at the different stages of the process.

The gradual fall in temperature and total viable count towards the end of process indicate the depletion of nutrients and the process approaching stability, hence less heat was generated. The temperature values recorded in the system during the composting period show that only thermophilic conditions were created.

The bacteria identified during the process were Bacillus spp., Staphylococcus spp., Streptococcus spp., Clostridium spp., Campylobacter spp., Listeria spp., Corynebacterium spp., Yersinia spp and Enterobacter spp. Table I.1 in Appendix I shows that Bacillus spp. (42.86\%) and Cornybacterium spp. $(57.14 \%)$ survived the process and these were the organisms found in the starter used to facilitate the decomposition process.

\subsubsection{Total Coliform Count}

The total coliform count decreased during week 0 to week 2 from $7.21 \log \mathrm{CFU} / \mathrm{g}$ of compost to $5.85 \mathrm{log} \mathrm{CFU} / \mathrm{g}$ of compost with temperature rise from $52.49^{\circ} \mathrm{C}$ to $65.44{ }^{\circ} \mathrm{C}$ as seen in figure 8. Further fall in temperature from $65.44^{\circ} \mathrm{C}$ to $61.07^{\circ} \mathrm{C}$ in week 2 to week 4 led to a fall in the total coliform count from $5.85 \log \mathrm{CFU} / \mathrm{g}$ of compost to 0 , indicating the reduction in faecal contamination. Enterobacter spp. was the only coilform identified.

\subsubsection{Total Fungi Count}

Figure 8 shows a rise in total fungi count from $1.11 \log \mathrm{CFU} / \mathrm{g}$ of compost to $2.25 \log \mathrm{CFU} / \mathrm{g}$ of compost with rise in temperature from $52.49^{\circ} \mathrm{C}$ to $65.44^{\circ} \mathrm{C}$ during week 0 to week 2 . The subsequent weeks experienced fluctuations in the total fungi count with a fall in temperature from week 3 to week 7 . The total fungi count began increasing during week 8 to week 12 from $1.76 \log \mathrm{CFU} / \mathrm{g}$ of compost to $2.06 \log \mathrm{CFU} / \mathrm{g}$ of compost with a fall in temperature from $53.80^{\circ} \mathrm{C}$ to $45.19^{\circ} \mathrm{C}$. The total fungi count recorded during week 12 was greater than that obtained in week 0 . This confirms the fact that fungi are less tolerant to high temperatures and also are responsible for the decomposition of cellulose which are high during the latter stages of composting (Compost Microbiology and Soil Microbiology Web, 2008).

The various fungi identified during the process were Penicillium spp., Aspergillus spp., Mucor spp. and Rhizopus spp., with only Penicillium spp. surviving the process at the end of week 12 .

\subsubsection{Germination Index}

Germination index increased from $82.54 \%$ in week 0 with falls in week 1, week 4 , week 7 and week 10 and rises during the other weeks till week 12 when $198.11 \%$ was recorded for the germination index as shown in fig. 9. The temperature also increased from $52.49^{\circ} \mathrm{C}$ to $65.44^{\circ} \mathrm{C}$ from week 0 to week 3 and then fell gradually to $45.19^{\circ} \mathrm{C}$ in week 12 . The rise in germination index from $82.54 \%$ to $198.11 \%$ denotes the increase in decomposition and maturity of the mass from week 
0 to week 12 . The gradual fall in temperature toward week 12 denotes the depletion of nutrients, hence less heat generation.

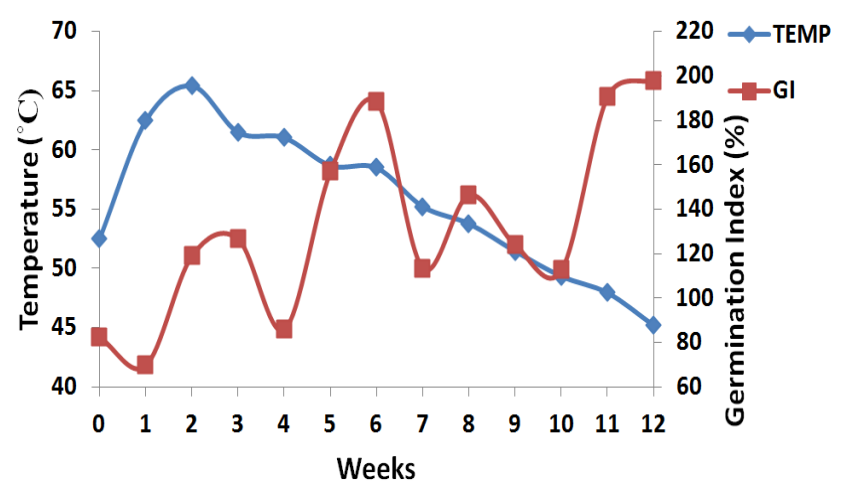

Figure 9. Variations in Temperature and Germination Index in the HV system.

However, when the germination index curve was compared with the total viable count and total fungi count, it was observed from figure 10 that as total fungi count and total viable count rose during week 1 , the germination fell. In week 2 , rise in total viable count and fungi count gave a rise in germination index. During week 3, the germination index increased with reduction in the total fungi count whereas in week 6 , the germination index decreased as the total fungi count increased and total viable count decreased. This indicates that the fungi present were using the nutrient during the early stage of composting hence the low germination index recorded with rises in the fungi count. However, from week 10 to week 12 , as the total fungi increased and the total viable count decreased, the germination index increased. This confirm the fact that fungi dominated the process at the end to decompose the cellulose, chitin and lignin coupled with the low temperature that favour their growth as reported in Compost Microbiology and Soil Food Web (2008).

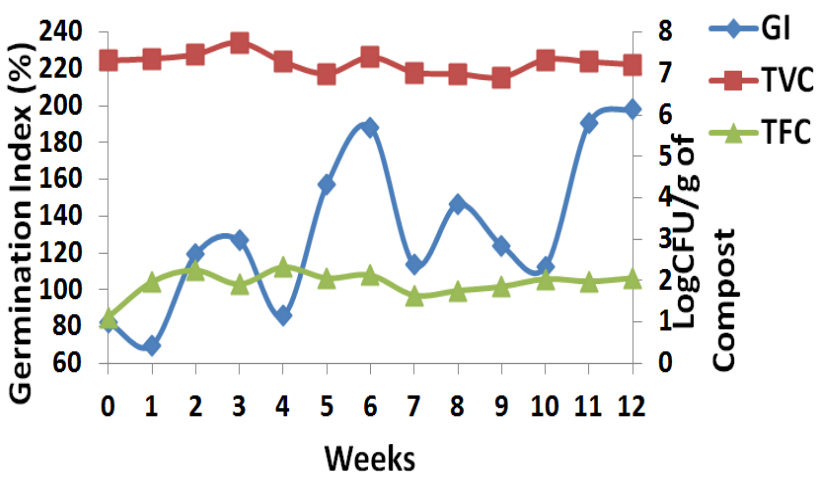

Figure 10. Variations in Germination Index, Total Viable Count and Total Fungi Count in HV system .

\subsection{Comparative Analysis of Parameters Determined in the Two Systems}

\subsubsection{Temperature}

Temperature values ranged between $45.19^{\circ} \mathrm{C}-65.44^{\circ} \mathrm{C}$ and $37.89^{\circ} \mathrm{C}-62.56^{\circ} \mathrm{C}$ in $\mathrm{HV}$ and $\mathrm{T}-\mathrm{W}$ respectively. There were significant differences in temperatures recorded in the different systems during the composting period ( $\mathrm{p}$-value $=$
$4.75 \times 10-7$, at $\alpha=0.05)$. The T-W system recorded lower temperatures and these can be accounted for by the turning of the compost mass to increase aeration. Different microbes were found in the compost masses in each system at different times a result of the different temperatures recorded in the two systems at various times.

\subsubsection{Total Viable Count}

The total viable counts recorded in HV, FA and T-W ranged between $6.90-7.75 \log \mathrm{CFU} / \mathrm{g}$ of compost and 7.11 $-7.79 \log \mathrm{CFU} / \mathrm{g}$ of compost respectively. There was significant differences between the total viable count recorded in the systems ( $p$-value $=0.027$, at $\alpha=0.05$ ). The fall in the total viable counts towards the end of the process also suggested the depletion of nutrients.

\subsubsection{Total Coliform Count}

The total coliform counts ranged between 5.30 $7.21 \log \mathrm{CFU} / \mathrm{g}$ of compost and $5.70-6.88 \log \mathrm{CFU} / \mathrm{g}$ of compost $\mathrm{HV}$ and $\mathrm{T}-\mathrm{W}$ respectively for the initial four weeks. However, during week 4 to week 12, the total coliform counts reduced to $0.00 \log \mathrm{CFU} / \mathrm{g}$ of compost in the various systems studied.

\subsubsection{Total Fungi Count}

The total fungi counts recorded in $\mathrm{HV}$ and $\mathrm{T}-\mathrm{W}$ ranged between $1.11-2.32 \log \mathrm{CFU} / \mathrm{g}$ of compost and 1.68 $2.40 \log \mathrm{CFU} / \mathrm{g}$ of compost respectively. The total fungi counts recorded in the two systems during the initial week were lower compared to those recorded during the final week except for the T-W system. The decreased moisture contents, temperatures and the presence of large cellulolytic materials in $\mathrm{HV}$ system supported the increase in the total fungi count during the latter week of composting while the low total fungi count recorded in $\mathrm{T}-\mathrm{W}$ system during the final week might have been due to the turnings effected in the compost mass, which consequently resulted in the early decomposition of celluloytic materials.

\subsubsection{Germination Index}

The germination indices recorded were used as a measure of the rate of decomposition and maturity. Germination indices recorded in the two systems were low but considerably increased during the latter weeks due to the release of nutrients by microorganisms. The germination indices ranged between $82.54 \%-198.11 \%$ and $88.58 \%-222.64 \%$ for compost masses in $\mathrm{HV}$ and $\mathrm{T}-\mathrm{W}$ respectively. Compost masses in all the systems had germination indices more than $150 \%$ at the end of week 12. Systems T-W had a higher rate of decomposition, hence faster maturity than systems HV; because they had final germination indices of $222.64 \%$ and $198.11 \%$ respectively.

\subsubsection{Microbial Community}

Different bacteria were identified in the different systems at different stages of the composting and their frequency decreased at different times due to variation in temperatures recorded in the systems. Bacillus spp., Staphylococcus spp., Streptococcus spp., Clostridium spp., Campylobacter spp., Listeria spp., Corynebacterium spp., Yersinia spp. and 
Enterobacter spp. were the bacteria identified during the different phases of the composting process in all the systems.

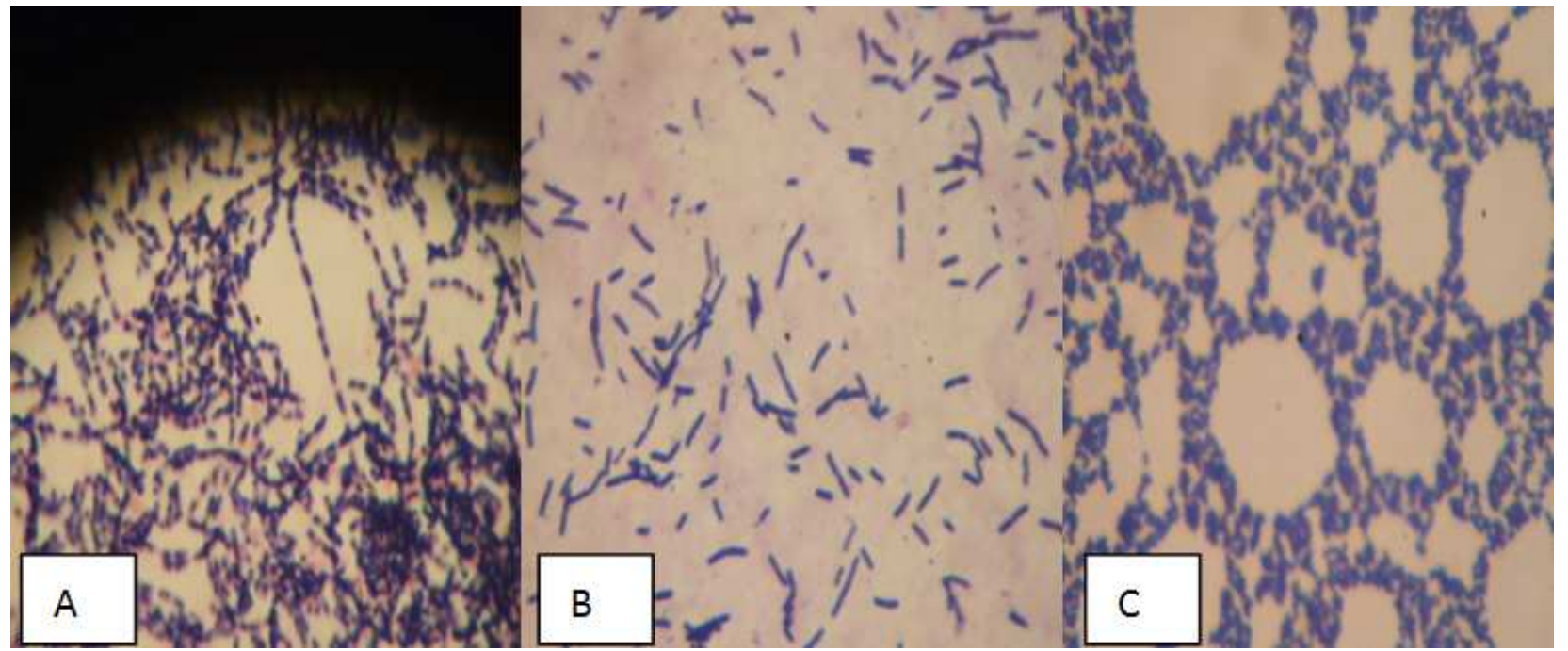

Figure 11. Bacillus spp., A; Corynebacterium spp., B; Staphylococcus spp., C viewed under microscope.

Bacillus spp. (42.86\%) and Corynebacterium spp. (57.14\%) and $(71.43 \%)$ survived the process in HV and T-W system respectively. Among the fungi identified in the two systems such as Aspergillus spp., Penicillium spp., Mucor spp. and Rhizopus spp., only Penicillium spp. (100\%) survived in both systems.

\section{Conclusion}

The germination indices obtained from the compost masses in both systems revealed they were higher that $150 \%$, indicating that both systems churned out matured compost. However compost in T-W seems to have a higher rate of decomposition, hence faster maturity comparatively. It therefore serves a better choice in terms of maturity. In addition identical microorganisms survived in both systems; but Bacillus spp. and Corynebacterium spp. were organisms used as starter to facilitate decomposition of compost in both systems. However the only fungi that survived in both systems Penicillium spp. produces mycotoxins such as citrinin, luteoskyrin, ochratoxins and rubratoxin which cause illnesses in humans. Luteoskyrin is associated with high incidence of liver cancer in humans.

It thus can be recommended that compost end-users, farmers, and producers must wear protectives such gloves and observe good hygiene when handling compost in other to safeguard their health.

\section{References}

[1] Ben-Yephet, Y. \& Nelson, E.B. Differential suppression of damping-off caused by Pythium aphanidermatum, P. irreulare, and P. myriotylum in composts at different temperatures. Plant Diseases, 83:356-360, 1999.

[2] Collins, C.H. \& Lyne, P.M. Microbiological Methods. 5th ed. Butterworth and Co, London,1983, pp.5, 89.
[3] Composting Council of Canada. A Summary of Compost Standards in Canada. Available at: www.compost.org/ standard.html, 2008. (accessed on 31 May 2015).

[4] Compost Microbiology and the Soil Food Web 2008. Available at: http://w ww.ciwmb.ca.gov /publications/Organics/, 2008 (accessed on 5 January 2015).

[5] Cunha Queda, A.C., Vallini, G., Agnolucci, M., Coelho, C.A., Campos, L. \& de Sousa, R.B. Microbiological and chemical characterization of composts at different levels of maturity, with evaluation of phytotoxicity and enzymatic activities. In:Insam, H., Riddech, N., Krammer, S. (Eds.), Microbiology of Composting. Springer Verlag, Heidelberg, pp. 345-355, 2002.

[6] Epstein, E. The Science of composting. Technomic Publishing Company, Inc., Lancaster, PA, 1996.

[7] Garcia, C., Hernandez, T., Costa, F. \& Ayuso, M. Evaluation of the maturity of municipal waste compost using simple chemical parameters. Commun. Soil Sci. Plant Anal, 23:1501-1512, 1992.

[8] Hao, X.Y., Chang, C., Larney, F.J. \& Travis, G.R. Green gas emissions during cattle feedlot manure composting. J. Environ. Qual., 30:376-386, 2001.

[9] Hoitink, H.A., Stone, A.G., and Han, D.Y. 1997,Suppression of plant diseases by compost HortScience, 32:184 -187, 1997.

[10] Hue, N.V. \& Liu, J. Predicting compost stability. Compost Science and Utilization, 3:8-15, 1995.

[11] Ikeda, K., Koyama, F. Takamuku, K. \& Fukuda, N. The Efficiency of Germination Index Method as a Maturity Parameter for Livestock Faeces Composts. Bulletin of the Fukuoka Agricultural Research Center, 25: 135-139, 2006.

[12] Inbar, Y., Chen, Y., and Hoitink, H.A. 1993, Science and engineering of composting: design, environmental, microbiological and utilization aspects, H.A.J.Hoitink and $\mathrm{H}$. M. Keener (Eds.), Renaissance Publications, Worthington, $\mathrm{OH}$, $669,1993$. 
[13] Lopez-Real, J. \& Baptista, M. A preliminary comparative study of three manure composting systems and their influence on process parameters and methane emissions. Compost Sci. Util., 4:71-82, 1996.

[14] Sherman, R. Large-scale organic materials composting. North Carolina Cooperative Extension Service. Available at: http://www.bae.

ncsu.edu/bae/programs/extension/publicat/vermcompost/ag59 3 .pdf., 2005( accessed on 23 January 2015).

[15] Strom, P.F. Effect of temperature on bacterial species diversity in thermophilic solid-waste composting. Applied and Environmental Microbiology, 50(4): 899-905, 1985.
[16] Sundberg, C. Improving Compost Process Efficiency by Controlling Aeration, Temperature and PH. Doctoral Thesis No.2005:103, Faculty of Natural Resources and Agriculture, Swedish University of Agricultural Sciences, Sweden, pp. 10,11,16-17, 2005

[17] USDA. Composting. Part 637, National Engineering Handbook, NRCS, U.S. Department of Agriculture, Washington, D.C., 2002.

[18] Zucconi, F., Forte, M., Monaco, A. \& De Bertoldi, M. Biological evaluation of compost maturity. BioCycle, 22: 27-29, 1981. 